\title{
The Effectiveness of Gestural Communication Means for Displaying Emotions with Reference to Kurdish and English
}

\section{Zaynab Ramzi Hussein}

Department of English, College of Languages, University of Salahaddin, Erbil, Kurdistan Region Iraq

Zaynab.ramzi94@gmail.com

Asst. Prof. Dr. Wrya Izzadin Ali

Department of English, College of Languages, University of Salahaddin, Erbil, Kurdistan Region Iraq wryaizzadin@yahoo.com

\section{ARTICLE INFO}

\section{Article History:}

Received: 2/5/2021

Accepted: 8/6/2021

Published: Summer 2021

Keywords: Nonverbal communication, Gestures, Emotion, Display rules, Gestural communication.

Doi:

10.25212/lfu.qzj.6.3.32

\section{ABSTRACT}

This study aims at investigating the effectiveness of gestural communication means in displaying emotions. Nonverbal communication is an important part of linguistic studies and has always played an important role in face-toface communication. Words are best explained when they are used with gestures and body movements especially in face to face interactions. Therefore, gestures are very effective in communicating emotions and they add up to what people say verbally. Yet expressing and displaying emotions depend on social and cultural rules.

The paper concludes that there is a significant similarity between gestures of English societies and Kurdish society. Moreover, people pay attention to gestures a lot, but their occurrence depends on social shared rules and norms of the society. 


\section{QALAAI ZANISTSCIENTIFIC JOURNAL \\ A Scientific Quarterly Refereed Journal Issued by Lebanese French University - Erbil, Kurdistan, Iraq \\ Vol. (6), No (3), Summer 2021 \\ ISSN 2518-6566 (Online) - ISSN 2518-6558 (Print)}

\section{Introduction}

Human language cannot be limited to spoken or written forms since language can be expressed by visual means too. Particularly when people cannot overtly or linguistically express their feelings, they try to use less consensual forms such as gestures (Mehrabian, 1971; Cowles, 2010).

Verbal communication mainly conveys information and ideas, while nonverbal channels of communication can negotiate interpersonal attitudes and emotions (Pease, 1981).

Adam Kendon describes gestures as visible movements of any part of the body that encompasses an intention of communication, but not everything a person does assigns meaning. He also shows that gestures do not only include hand or arm gestures but also head movements, gaze direction, movements of eyebrows, nostrils and lips and the general name for the linguistics study of coordinated movements of body related to communication is called Kinesics, cited in (Calbris, 2011; Eunson, 2012).

Linguists state that gestures play an important role in nonverbal communication since human beings have expressive hands, arms and head. Therefore, they are helpful in accompanying speech. Gestures act like a pivot between the concrete image of an action and the abstract reference. For instance, gestures express something which is a part of the meaning that the speaker is trying to convey. In addition, gestures help the speaker in contributing the process of communication and how the speaker is understood by the listener. These are the reasons why gestures are used widely in face to face interactions (Andersen, 1999; Calbris, 2011; Carleo, 2005).

Many researchers state that gestures are culture-dependent as languages vary from one culture to another gestural communication varies too. An example of culturedependent gesture is that pointing to chest in most of the western societies mean (I or me). While Chinese and Japanese people point to their nose to indicate (I or me). (Steinberg and Sciarini, 2013). 


\section{QALAAI ZANISTSCIENTIFIC JOURNAL \\ A Scientific Quarterly Refereed Journal Issued by Lebanese French University - Erbil, Kurdistan, Iraq \\ Vol. (6), No (3), Summer 2021 \\ ISSN 2518-6566 (Online) - ISSN 2518-6558 (Print)}

\subsection{The Aims of the Study}

This study aims at:

1. Investigating the role of gestural communication in displaying emotions.

2. Exploring the gestures that show emotion in English culture and examine if they are similar or different in Kurdish culture.

3. Illustrating the cultural ways of thinking in understanding the messages and displaying emotions.

\subsection{Research Questions}

1. Do the gestures used by English people refer to the same emotions in the Kurdish society?

2. Are displaying rules important in communicating emotions?

3. Are gestures effective in displaying emotions and do they add to what people say verbally?

\subsection{The Significance of the Study}

The importance of this study lies in the fact that gestures are important in face to face interactions as they add visual and emotional emphasis to one's speech. Gestures can be differentiated with how closely are they related to speech, and how conventionalized are they? The meaning of gestures can vary from one context to another, from one culture to another. Therefore, studying gestures with their specific emotional meaning plays an important role in communication since they add more meanings than what is said verbally.

\subsection{Language as a means of communication}

Communication is the core of human daily life that plays a significant role in human activities. In society, individuals attempt to share their ideas, thoughts, emotions and reactions. Therefore, communication has become a necessary element in human interactions or relationships (Bhardwaj, 2008; xv).

Numerous studies have been coming out on the concept of language and communication. There are many definitions of communication. Gumperz (1982:1) defines Communication as "a social activity that requires at least two individuals to produce a message, only when the message elicits a response that means 


\section{QALAAI ZANISTSCIENTIFIC JOURNAL \\ A Scientific Quarterly Refereed Journal Issued by Lebanese French University - Erbil, Kurdistan, Iraq \\ Vol. (6), No (3), Summer 2021 \\ ISSN 2518-6566 (Online) - ISSN 2518-6558 (Print)}

communication is happening."

\subsection{Types of communication:}

Communication can be divided into two types:

\subsubsection{Verbal means of communication}

Verbal communication is an important aspect of human evolution which consists of the linguistic features of communication. In verbal communication, people use symbols that have universal meanings for both the sender and receiver. The symbols can be spoken or written and they are known as languages (Barker, 1984; Crystal, 2008).

\subsubsection{Non-verbal means of communication}

Non-verbal communication is an important aspect of communication that plays a significant role in human activities. Knap (2013: 8) defines nonverbal communication as a "communication affected by means other than words".

Nonverbal communication consists of many channels for example, paralinguistic, haptic, proxemics, facial expressions, postures and gestures. Facial expressions are mostly innate, gestures are different from one culture to another, touch is usually taboo and so on (Argyle, 1988). Some of the nonverbal channels are naturally controllable such as touch or proxemics. While some of them are not naturally controllable like, sweating, sexual pleasure, blushing, yawning and pupil dilation (Furnham and Petrova, 2010).

To conclude and going through these definitions, nonverbal communication can be defined as "communication that occurs without the use of words" not only verbal communication can convey a meaning sometimes a smile, a frown or a glance can convey a message" (Bhardwaj, 2008).

Hence, nonverbal communication means can convey meanings as much as words do. 


\section{QALAAI ZANISTSCIENTIFIC JOURNAL \\ A Scientific Quarterly Refereed Journal Issued by Lebanese French University - Erbil, Kurdistan, Iraq \\ Vol. (6), No (3), Summer 2021 \\ ISSN 2518-6566 (Online) - ISSN 2518-6558 (Print)}

\subsection{Gestures}

Gestures are a type of nonverbal communication delivered by the movements of the body. Gestures include hand, arm, head movements. The linguistics study of the body related to communication is called Kinesics, cited in (Calbris, 2011; Eunson, 2012).

Studdert-Kennedy (1987) claims gestures as articulatory movements are an important communicative function, whether produced intentionally or not. (Armstrong et al., 1995). Gestures are used to convey messages such as greetings, requests, commands, insults, answers, descriptions, evaluations and expressing emotions. For instance, touching or itching one's face implies suspicion, doubt or concern. (Carleo, 2005; Steinberg and Sciarini, 2013).

Gestures are tightly connected to speech. The Broca's area which is responsible for speech production in the human brain also activates gestures. In an experiment, a study concluded that children who keep their hands motionless have difficulty in remembering memorized topics. (Goman, 2008: 84)

Gestures are rarely universal, but are often similar. Similar gestures though may differ in meaning due to cultural and geographical reasons. Researchers define gestures as culture-dependent, for example: Westerners point to their chest to say I or me, whereas Chinese and Japanese point to their nose. (Steinberg and Sciarini, 2013).

Birdwhistell (1970: 81) states that there are no gestures that have similar meaning in all societies and gestures are not universal. Whereas Pease (1981) found some gestures that carry the same meaning in all societies, such as nodding to say 'yes', or shaking head side to side to say 'no'. He points out how deaf and blind people use these gestures and how babies say 'no' when they have enough milk.

\subsection{Types of Gestures:}

Ekman and Friesen (1969) classified hand gestures as following:

\section{Emblems}

Emblems or speech-independent gestures have explicit meaning and specific definitions similar to words. Emblems are used as substitutes for words. Within a culture emblem can be used and recognized to convey a meaning. (Andersen, 1999; Goman, 2008a; Furnham and Petrova, 2010; Kendon, 1981). 


\section{QALAAI ZANISTSCIENTIFIC JOURNAL \\ A Scientific Quarterly Refereed Journal Issued by Lebanese French University - Erbil, Kurdistan, Iraq \\ Vol. (6), No (3), Summer 2021 \\ ISSN 2518-6566 (Online) - ISSN 2518-6558 (Print)}

Emblematic gestures represent a whole thought and have a standard meaning. They can complete an utterance and fill a grammatical slot because emblems are produced on the left hemisphere. Kissing, sticking out one's tongue, and waving hand as "hello" and similar gestures are expressions that culturally vary. (Goman, 2008; McCfferty and Stam, 2008).

Such gestures are consciously used though like slips of tongue; slips of gesture are possible. Because the head, arm, hand, and facial muscles are used, a single gesture can be in more than one category.

\section{Illustrators}

Illustrators are the most common type of gestures also known as speech-related gestures. They include hand and arm movements and are directly tied to speech. They function depending on their relatedness to speech and how they are used. (Andersen, 1999; Furnham and Petrova, 2010; Knapp et al., 2014).

Illustrators do not occur without speech. A person's mood and the conversation affect its use. A demoralized person is more likely to use less illustrators and a speaker with lack of words might use it frequently. (Mortenson, 2008).

Illustrators can be classified as following:

1. Batons are hand and arm movements that accent or emphasize a particular word. For example, the chopping or punching gestures of politicians.

2. Ideographs trace or sketch an idea. E.g., lowering or raising one's hand when saying "decrease" or "increase".

3. Pictographs are drawing a picture of the referent in the air, such as drawing the hour glass shape to refer to a woman.

4. Kinetographics illustrate human bodily or nonhuman physical actions as when a witness imitates the criminal's actions.

5. Rhythmic movements show the rhythm or the timing of an event.

6. Spatials are gestures that show size or distance. When a fisherman spreads his arms to show the size of a fish.

7. Deictic movements point to a place or an object. When a teacher points to a student to call her/him.

8. Emblematic movements are emblems that substitute a statement. For instance, 


\section{QALAAI ZANISTSCIENTIFIC JOURNAL \\ A Scientific Quarterly Refereed Journal Issued by Lebanese French University - Erbil, Kurdistan, Iraq \\ Vol. (6), No (3), Summer 2021 \\ ISSN 2518-6566 (Online) - ISSN 2518-6558 (Print)}

making a circular motion to one's head as to say "He's crazy". (Andersen, 1999; Mortensen, 2008).

\section{Adaptors}

Adaptors are touching behavior's that display anxiety-based emotions. Adaptors help with dealing with discomfort and unsettling thoughts, adapting to a situation or feelings. However, they are unconscious and unrelated to the topic. (Allen, 2019; Andersen, 1999; Furnham and Petrova, 2010).

Adaptors are three kinds: (Allen, 2019; Andersen, 1999; Furnham and Petrova, 2010).

1. Self-adaptors are self-comforting behaviors. They can display one's emotional state or level of excitement or anxiety. For example, Rubbing or touching the face, the arms or torso.

2. Object adaptors are nervous behavior's that use objects like accessories, cigarettes, drinks, etc. They usually signal boredom. for instance, Playing with a pen, pencil, ring or rosary by men.

3. Other (alter) adaptors are made as a response to another person. For example, putting one's hands on the arms as a defense when someone gets into their personal space.

\section{Regulators}

According to Burgoon et al., 2010; Furnham and Petrova, 2010; Hartley and Karinch, 2007, Regulators make the conversations better, encourage others to talk, maintain the flow of the conversation, or control others' speech. People notice the regulators when they feel the lack of it in conversations because regulators hold listeners' attention, such as nodding, shutting someone up by putting index finger on the lips, dropping arms to end a speech, clasping one's hands behind their back to show superiority, showing palms to make a stop, rotating hands quickly as to say "speed it up".

\section{Affect Displays}

Affect displays are gestural expressions of emotions. Facial expressions display emotions naturally, they are universal. However, most of the gestures depend on 


\section{QALAAI ZANISTSCIENTIFIC JOURNAL \\ A Scientific Quarterly Refereed Journal Issued by Lebanese French University - Erbil, Kurdistan, Iraq \\ Vol. (6), No (3), Summer 2021 \\ ISSN 2518-6566 (Online) - ISSN 2518-6558 (Print)}

cultural rules and context. (Burgoon et al., 2010; Furnham and Petrova, 2010; Wainwright, 2009).

Affect displays occur also when a person is alone, or in child care, or when mating. They don't signal thoughts because thoughts are personal and involuntary. (Ekman, 1992).

Gestures that can display emotional states:

1. Clenched fist usually show anger.

2. Finger in mouth is often shame, doubt, or anxiety.

3. Rubbing hands is a common gesture, but context dependent. It can mean excited expectancy, or that someone is cold depending on the context.

4. Steepling hands are both positive and negative. Often it signals superiority or confidence, hence the underlying pride.

5. The three wise monkey gesture means "Hear no evil, see no evil, and speak no evil." Covering the mouth, ears and eyes often signal dishonesty, uncertainty, and shame. In some cases, they mean femininity or shyness.

6. Touching cheek, chin, or jaw means thinking, making decisions, boredom, or sadness.

7. Folding arms or using an object like cups, books as a barrier is associated with sadness, nervousness, or defensiveness.

8. Putting both hands behind the back or head signals authority, pride, and confidence.

9. Straightening tie for men is a gesture usually used in situations that involve courtship.

10. Clenched hands on the desk or lap, or near the face show frustration, low confidence, or sadness.

11. Biting nails or pencils shows stress, anxiety, or fear.

12. Rubbing the back of the neck signals frustration.

13. Women touch their neck when feeling anxious, stressed or shameful.

14. Supporting the chin by a hand with an index finger on the cheek shows critical thinking about a subject.

15. The hand on the heart shows love, attraction, or loyalty. 


\section{QALAAI ZANISTSCIENTIFIC JOURNAL \\ A Scientific Quarterly Refereed Journal Issued by Lebanese French University - Erbil, Kurdistan, Iraq \\ Vol. (6), No (3), Summer 2021 \\ ISSN 2518-6566 (Online) - ISSN 2518-6558 (Print)}

16. Covering the nose with both hands shows surprise.

17. Raised arms show happiness and gratitude.

18. Covering the face with hands shows fear.

19. Pushing something shows disgust.

(Goman, 2008; Furnham and Petrova, 2010; Pease. 1981).

\subsection{Emotional Communication}

Humans experience similar emotions and communicate them verbally and nonverbally. This communication helps people to understand each other and adjust themselves accordingly. It's proven that there is an automatic link between emotions and nonverbal channels (Andersen, 1999; Carleo, 2005; DePaulo, 1992).

Recognition of emotions helps people to fit in their environment. Gestures are effective ways to express emotions, especially in cases of denying misconceptions and verbal inability to communicate emotions. (Andersen, 1999). However, people face difficulties in interacting with people of different cultures because emotional reactions are interpreted differently by cultures. Cultural differences are a barrier in effective communication. This leads to the concept of display rules (Mehrabian, 1971).

\subsection{Display Rules}

According to Ekman and Friesen, 2003; Anderesen, 1999, display rules mask, exaggerate, or modify emotional expressions. They reflect pragmatic rules, norms, customs, and social appropriateness of expressing emotions. (Burgoon et al., 2010; Guerrero and Floyd, 2008).

People experience emotions all over the world, but cultural and social conventions obligate masking and controlling these experiences in public. For example, in the United States people set a display rule by telling young boys "little men do not cry".

Children learn display rules by imitating and observing their parents, friends, characters, or the internet. Learning these behaviours is called socialization. (Ekman and Friesen, 2003). 


\section{QALAAI ZANISTSCIENTIFIC JOURNAL \\ A Scientific Quarterly Refereed Journal Issued by Lebanese French University - Erbil, Kurdistan, Iraq \\ Vol. (6), No (3), Summer 2021 \\ ISSN 2518-6566 (Online) - ISSN 2518-6558 (Print)}

Children conceal, control, or falsify their emotions depending on situations. These learned display rules become a habit and unconscious behaviour after some time. The established rules are noticed only when violated. For example, a person shouldn't look happy around a misfortune one. Even babies turn their faces when they see angry people.

However, in some cultures funerals celebrate someone's life and people look happy, in other cultures it is a sad event. (Burgoon et al., 2010; Ekman, 1992; Ekman and Friesen, 2003; Fast, 1994; Guerrero and Floyd, 2008).

Men are taught to show fewer emotions; hence they have fewer gestures. However, Fast (1994) states that human reason can change and reshape those rules. Navarro and Karlins also state that "any person possessing normal intelligence can learn to use nonverbal communication to better themselves". People can better themselves according to their own rules and cultures. $(2008 ; 6)$.

There are five cultural display rules:

1. Simulation is the need of showing an unfelt emotion. As in receiving a gift, the receiver may act being happy about it.

2. Intensification or maximization is the need of showing more intense emotion. Crying at the funeral of an uncle when the person doesn't know or like him is an example.

3. Miniaturization is decreasing the intensity of emotions. When a young boy is threatened and shows less fear than he feels.

4. Masking is displaying a completely different emotion. For example, showing sadness for an enemy's failure.

5. Inhibition is the act of showing no emotions. When one is attracted to someone and doesn't show it, or when someone conceals their guilt to avoid detention. (Anderesen, 1999; Burgoon et al., 2010).

\section{Methodology}

\subsection{Design of the study}

The study employed a survey research design to collect data from the participants to investigate the effectiveness of gestures in displaying emotions. This research is quantitative in nature. Therefore, the design of this study is survey research. 


\section{QALAAI ZANISTSCIENTIFIC JOURNAL}

A Scientific Quarterly Refereed Journal Issued by Lebanese French University - Erbil, Kurdistan, Iraq

Vol. (6), No (3), Summer 2021

ISSN 2518-6566 (Online) - ISSN 2518-6558 (Print)

\subsection{Participants}

The total number of the participants who participated in this study was 75 , all of whom were the students of English department/ College of Languages/ Salahaddin and all of them were senior year students. Participants included both male and female students. The average age of students was about 21-26.

\subsection{Data collection}

Data were collected through a close-ended questionnaire. The questionnaire with 28 items, were given to 75 students. Participants responded by indicating their level of agreement with each of the questionnaire items.

\subsection{Data analysis}

The collected data were analyzed through Statistical Package for Social Sciences 'SPSS'. In order to examine the mean of gestures which have same or similar meanings to Kurdish people and if they add to what people say verbally or not?

\subsection{Findings and analysis}

Research question 1: Do the gestures used by English people refer to the same emotions in the Kurdish society?

\begin{tabular}{|l|r|r|}
\hline \multicolumn{1}{|c|}{ Table 1: gestures and their meanings } & \multicolumn{1}{|c|}{$\begin{array}{c}\text { Std. } \\
\text { Deviation }\end{array}$} \\
\hline $\begin{array}{l}\text { Questionnaire items } \\
\text { 1. People clench their fists when they are angry. }\end{array}$ & Mean & 1.241 \\
\hline $\begin{array}{l}\text { 2. Women put their finger over their mouth when they feel } \\
\text { ashamed. }\end{array}$ & 3.11 \\
\hline $\begin{array}{l}\text { 3. When people have happiness expectancy, they usually rub their } \\
\text { hands that. }\end{array}$ & 3.31 & 1.000 \\
\hline $\begin{array}{l}\text { 4. When people steeple their hands that means they feel confident, } \\
\text { superior and proud. }\end{array}$ & 3.67 & .890 \\
\hline $\begin{array}{l}\text { 5.Covering the mouth, the ears and the eyes or 'three wise monkeys' } \\
\text { gestures display shame, uncertainty or anxiety }\end{array}$ & 2.31 & 1.127 \\
\hline $\begin{array}{l}\text { 6. Touching cheek, chin or jaw is associated with thinking, boredom } \\
\text { and sadness. }\end{array}$ & 3.64 \\
\hline 7. Raised arms show happiness and gratitude. & 3.05 & 1.111 \\
\hline 8.Covering the nose with both hands displays surprise & 3.68 & 1.164 \\
\hline
\end{tabular}




\section{QALAAI ZANISTSCIENTIFIC JOURNAL}

A Scientific Quarterly Refereed Journal Issued by Lebanese French University - Erbil, Kurdistan, Iraq

Vol. (6), No (3), Summer 2021

ISSN 2518-6566 (Online) - ISSN 2518-6558 (Print)

\begin{tabular}{|c|c|c|}
\hline 9.The hand on heart signals attraction, love or loyalty & 2.91 & 1.296 \\
\hline $\begin{array}{l}\text { 10. Women touch their neck when they feel anxious, stressed or } \\
\text { ashamed }\end{array}$ & 3.20 & 1.000 \\
\hline 11.Rubbing the back of the neck signals frustration & 2.99 & 1.168 \\
\hline 12.Covering the face with hands show fear & 3.43 & 1.016 \\
\hline $\begin{array}{l}\text { 13. Thumb displays when other fingers are in the pocket only thumb } \\
\text { is shown displays ego, dominance, aggressiveness, confidence, self- } \\
\text { importance }\end{array}$ & 3.27 & 1.107 \\
\hline 14. Biting nails or pencils displays stress, anxiety or fear & 3.65 & 1.145 \\
\hline $\begin{array}{l}\text { 15. Folding arms or using an object as barrier, e.g. bags, cups or } \\
\text { books are often associated with sadness, nervousness or } \\
\text { defensiveness }\end{array}$ & 3.27 & .963 \\
\hline $\begin{array}{l}\text { 16.The tie-straightening gesture of males is a courtship gesture } \\
\text { which is usually used in situations that involve love }\end{array}$ & 2.13 & 1.143 \\
\hline $\begin{array}{l}\text { 17. Hands clenched together in front of the face, on the desk or on } \\
\text { the lap signals negative emotions, such as frustration, hostile } \\
\text { anxiety, low confidence or sadness }\end{array}$ & 2.91 & .947 \\
\hline $\begin{array}{l}\text { 18. Gripping the hands behind the back displays the positive emotion } \\
\text { of confidence, fearlessness, authority, anger or pride }\end{array}$ & 3.21 & 1.211 \\
\hline $\begin{array}{l}\text { 19.Putting both hands behind the back of the head signals } \\
\text { dominance, confidence, authority or pride }\end{array}$ & 3.39 & 1.314 \\
\hline $\begin{array}{l}\text { 20. Supporting the chin by a hand with the index finger on the cheek } \\
\text { shows that the listener is critically thinking about the subject and } \\
\text { trying to evaluate an issue }\end{array}$ & 3.92 & 1.062 \\
\hline 21.The pushing something gesture shows disgust & 2.97 & 1.115 \\
\hline Total & 3.19 & 1.108 \\
\hline
\end{tabular}

According to the results shown in the table above, it can be seen that the most positively reported gestures are items 4, 6, 8, 14 and 20. As for item 4, "When people steeple their hands that means they feel confident, superior and proud.", the mean is 3.67. This means that most of the participants believed that people, steepling hands display confident, superior and proud.

With regard to item 6, "Touching cheek, chin or jaw is associated with thinking, boredom and sadness.", the mean is 3.64 . This again shows that this gesture has the same interpretation by the participants.

In addition, item 8 , which the mean is 3.68 shows that most participants believe that 


\section{QALAAI ZANISTSCIENTIFIC JOURNAL \\ A Scientific Quarterly Refereed Journal Issued by Lebanese French University - Erbil, Kurdistan, Iraq \\ Vol. (6), No (3), Summer 2021 \\ ISSN 2518-6566 (Online) - ISSN 2518-6558 (Print)}

covering the nose with both hands display surprise.

Moreover, item 14, the mean is 3.65 and out of 75 participants 51 of them agreed that biting nails displays stress, anxiety or fear and that's \%68 percent of the participants.

Furthermore, item 20, was the most positively reported gesture with the mean of 3.92 which is \%72 percent of the participant had positive responses towards supporting the chin by a hand with the index finger on the cheek gesture and believed that this gesture shows that the person is critically thinking about the subject and trying to evaluate an issue

Therefore, the similarity between the above mentioned gestures in English and Kurdish is extremely high.

However, according to the results, it can be seen that the most negatively reported gestures are items 5 and 16 . As for item 5 the mean is 2.31 which show that the participants disagreed that covering the mouth, the ears and the eyes or 'three wise monkeys' gestures display shame, uncertainty or anxiety.

In addition, item 16 the tie- straightening gestures is one of the gestures that can be seen in English societies which usually represents courtship and love; however, depending on the participants responses it can be clearly seen that out of 75 participants 51 of the participants were disagree with the meaning of this gesture because the mean is 2.13 and the participants had negative attitude towards this gesture that means $\% 68$ of the participants.

Besides, only \%16 percent of the participants had positive attitude and believed this gesture does show love.

The overall results show that gestures used by English speaking societies and Kurdish society refer to similar emotions with the mean of 3.19. The reason for that can be the universality of gestures.

As previously mentioned communicating emotions are universal human beings biologically experience emotions yet expressing them is dependent on display rules (Andersen, 1999). Displaying of emotion nonverbally can vary from one culture to another. However, gestures are culturally defined therefore, their meanings might be similar but not exactly the same (Steinberg and Sciarini, 2013) 


\section{QALAAI ZANISTSCIENTIFIC JOURNAL}

A Scientific Quarterly Refereed Journal Issued by Lebanese French University - Erbil, Kurdistan, Iraq

Vol. (6), No (3), Summer 2021

ISSN 2518-6566 (Online) - ISSN 2518-6558 (Print)

As Pease (1981) stated that gestures are similar all over the world but their meanings are different from one culture to another.

Research question 2: Are displaying rules important in communicating emotions?

Table 2: Display rules

\begin{tabular}{|l|c|c|}
\hline & Mean & $\begin{array}{l}\text { Std. } \\
\text { Deviation }\end{array}$ \\
\hline $\begin{array}{l}\text { 1. Sometimes I feel the need to show an emotion that I do not really } \\
\text { feel it, because of cultural rules and social appropriateness. }\end{array}$ & 3.27 & 1.143 \\
\hline $\begin{array}{l}\text { 2. Sometimes I feel the need to show more intense emotion than } \\
\text { what I really experience it, because of cultural rules. }\end{array}$ & 3.35 & 1.262 \\
\hline $\begin{array}{l}\text { 3. Sometimes I feel the need to decrease and display less intense } \\
\text { emotion than my real feeling. }\end{array}$ & 3.03 & 1.033 \\
\hline $\begin{array}{l}\text { 4. Sometimes I feel the need to display a completely different } \\
\text { emotion than the one that I experience. }\end{array}$ & 3.07 & 1.369 \\
\hline $\begin{array}{l}\text { 4. Sometimes I feel the need to show no emotions as if there was } \\
\text { not any emotion while I am actually feeling something. }\end{array}$ & 3.25 & 1.231 \\
\hline Total & 3.19 & 1.207 \\
\hline
\end{tabular}

In the above table of display rules the total mean is 3.19 which means participants agreed that the shared social rules of society have impact in how people display emotions and how much they show or they do not show.

Additionally, the most agreed question was item 2, which says ' Sometimes I feel the need to show more intense emotion than what I really experience it, because of cultural rules'. The result of this question shows that in some contexts people have to show more intense feelings than the ones they really feel. 


\section{QALAAI ZANISTSCIENTIFIC JOURNAL \\ A Scientific Quarterly Refereed Journal Issued by Lebanese French University - Erbil, Kurdistan, Iraq \\ Vol. (6), No (3), Summer 2021 \\ ISSN 2518-6566 (Online) - ISSN 2518-6558 (Print)}

Research question 3: Are gestures effective in displaying emotions and do they add to what people say verbally?

Table 3: Importance of gestures

\begin{tabular}{|l|r|r|}
\hline & \multicolumn{1}{|c|}{$\begin{array}{c}\text { Std. } \\
\text { Deviation }\end{array}$} \\
\hline 1. I pay attention to gestures. & 3.59 & 1.054 \\
\hline 2. Gestures add up to what someone is saying. & 3.61 & 1.051 \\
\hline Total & 3.6 & 1.052 \\
\hline
\end{tabular}

This research question aimed to show if gestures are really important in communication or not? The above table shows that the mean is 3.6 for both of the questions. As already mentioned, 75 participants responded to the questionnaire and 49 of them which is nearly $\% 65$ of the participants agreed that they do pay attention to gestures and gestures add up to what people is verbally. However only $\% 17$ of the participants disagreed, $\% 18$ of the participants was neutral.

\section{Conclusion}

The results of this study show that most of the gestures explained in this study that are used by English speaking societies and Kurdish society refer to similar emotions, yet there are differences in some specific gestures and they contradict. Some of the gestures do not refer to similar emotions by Kurdish people.

Moreover, cultural display rules have impact on how people display their actual emotions. Sometimes Kurdish people decrease or increase their feelings about a topic because of the shared rules of society.

Furthermore, according to the results it can be seen that gestures have a great role in communication. Most of the people are aware of the use of gestures in face to face situations. People do pay attention to gestures and what they change about what the person is saying verbally. 


\section{QALAAI ZANISTSCIENTIFIC JOURNAL \\ A Scientific Quarterly Refereed Journal Issued by Lebanese French University - Erbil, Kurdistan, Iraq \\ Vol. (6), No (3), Summer 2021 \\ ISSN 2518-6566 (Online) - ISSN 2518-6558 (Print)}

\section{REFERENCES}

Allen, H. (2019). Self Adaptors, Alter Adaptors and Object Adaptors in Nonverbal Communication. [online] Owlcation. Available at: https://owlcation.com/socialsciences/Self-Adaptors-Alter-Adaptors-and Object-Adaptors-in-NonverbalCommunication [Accessed 12 Feb. 2020].

Andersen, P. (1999). Nonverbal communication: forms and function. California: Mayfield Publishing Company.

Armstrong, D. F., Stokoe, W. C., \& Wilcox, S. E. (1995). Gesture and the nature of language. Cambridge: Cambridge University Press.

Armstrong, D. and Wilcox, S. (2007). The gestural origin of language. Oxford: Oxford University Press.

Argyle, M . 1988 . Bodily Communication. Methuen, London.

Bhardwaj, K. (2008). Professional communication. New Delhi: I.K. International Publishing House Pvt. Ltd.

Birdwhistell, R. (1970). Kinesics and Context Essays on Body Motion

Communication. PHILADELPHIA: University of Pennsylvania Press.

Burgoon, J., Guerrero, L. and Floyd, K. (2010). Nonverbal communication. London and Newyork: Taylor \& Francis

Calbris, G. (2011). Elements of meaning in gesture. Amsterdam/ Philadelphia: John Benjamins Publishing Company.

Crystal, D. (2008). A dictionary of linguistics and phonetics. 6th ed. Malden, Mass.: Blackwell Publishing.

Crystal, D. and Henry Robens, R. (2019). language / Definition, Characteristics, \& Change. [online] Encyclopedia Britannica. Available at: https://www.britannica.com/topic/language [Accessed 6 Sep. 2019].

Cohen, A. A. 1977. The communicative functions of hand illustrators. Journal of Communication 27: 54-63. 


\section{QALAAI ZANISTSCIENTIFIC JOURNAL \\ A Scientific Quarterly Refereed Journal Issued by Lebanese French University - Erbil, Kurdistan, Iraq \\ Vol. (6), No (3), Summer 2021 \\ ISSN 2518-6566 (Online) - ISSN 2518-6558 (Print)}

Cowles, H. (2011). Psycholinguistics. New York: Springer, p.153.

Ekman, P., Friesen, W. and Ellsworth, P. (1972). Emotion in the human face: $\quad$ guide-lines for research and an integration of findings. New York: Pergamon Press.

Ekman, P. (1992). Telling lies; clues to the deceit in the marketplace, politics, and Marriage. New York: W.W. Norton \& Company.

Ekman, P. (2003). Emotions revealed: Recognizing Faces and Feelings to improve Communication and Emotional Life. New York: Henry Holt and Company, LLC.

Ekman, P. and Friesen, W. (2003). Unmasking the face: A guide to recognizing emotions from facial clues. Cambridge (Mas.): Malor Books.

Eunson, B. (2012). Communicating in the 21st Century, 4th Edition. 3rd ed. John Wiley \& Sons Australia.

Fast, J. (1994). Body language in the workplace. New York, NY: Penguin Books (1971). Body language. London: Pan Books Ltd, Cavaye Place, London.

Furnham, A. and Petrova, E. (2010). Body Language in Bussiness Decoding the Signals. NewYork: Palgrave Macmillan.

Goman, C. (2008a). The nonverbal advantage. San Francisco, Calif.: Berrett Koehler Publishers.

(2008b). The nonverbal advantage :Secrets and Science of Body Language at Work. San Francisco, Calif.: Berrett-Koehler Publishers.

Guerrero, L. and Floyd, K. (2008). Nonverbal communication in close relationships. Mahwah, N.J.: Lawrence Erlbaum Associates.

Hartley, G. and Karinch, M. (2007). I can read you like a book how to spot the messages and emotions people are really sending with their body language. Franklin Lakes, N.J.: Career Press.

Kendon, A. (1981). Nonverbal communication, interaction, and gesture. Selections from Semiotica. Ed., (intr. by) Adam Kendon. The Hague Paris - New York: Mouton VIII. 


\section{QALAAI ZANISTSCIENTIFIC JOURNAL \\ A Scientific Quarterly Refereed Journal Issued by Lebanese French University - Erbil, Kurdistan, Iraq \\ Vol. (6), No (3), Summer 2021 \\ ISSN 2518-6566 (Online) - ISSN 2518-6558 (Print)}

Knapp, M., Hall, J. and Horgan, T. (2014). Nonverbal communication in human interaction. 8th ed. Boston, MA USA: Wadsworth, Cengage Learning.

McCafferty, S. and Stam, G. (2008). Gesture Second Language Acquisition and Classroom Research. New York and London: Routledge: Taylor \& Francis Group.

Mehrabian, A. (1971). Silent messages. Belmont, Calif.: Wadsworth Pub. Co.

Morris, D. (1995). Bodytalk A world guide to gestures. London: Jonathan Cape ...(2002). Peoplewatching. London: Vintage.

Mortensen, C. (2008). Communication Theory. New Brunswick: Transaction Publishers.

Navarro, J. and Karlins, M. (2008). What every BODY is saying. Pymble, NSW: HarperCollins e-books.

Pease, A. (1981). Body language. London: Sheldon Press.

Poyatos, F. (2002). Nonverbal communication across disciplines. Amsterdam: J. Benjamins Pub. Co.

Samovar, L., McDaniel, E., Porter, R. and Roy, C. (2013). Communication between cultures. Boston, Mass.: Wadsworth Cengage Learning.

Steinberg, D. and Sciarini, N. (2013). An Introduction to Psycholinguistics. $2^{\text {nd }}$ ed.Hoboken: Taylor and Francis.

Wainwright, G. (2009). Body language. London: Teach Yourself.

\section{كاريكهرى ئامازه جهستهييه كان له نيشاندانى ههستهكان له كوردى و ئينكليزى}

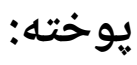

ئامانجى ئهم تويّزينهوهيه لِيكوَّلِينهوهيه له كاريكهرى ئامازه جهستهييهكان له نيشاندنى ههستهكان . يهيوهندى نازارهكى بهشيّكى گرنكى خويندنى زمانهوانييه و ههميشه رِوّلِيّكى گرنكى بينيوه له كفتو 


\section{QALAAI ZANISTSCIENTIFIC JOURNAL}

A Scientific Quarterly Refereed Journal Issued by Lebanese French University - Erbil, Kurdistan, Iraq

Vol. (6), No (3), Summer 2021

ISSN 2518-6566 (Online) - ISSN 2518-6558 (Print)

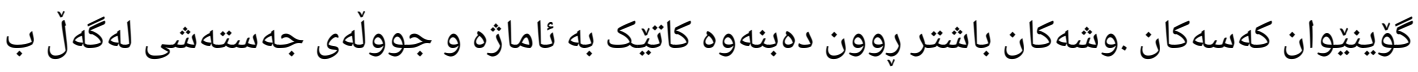

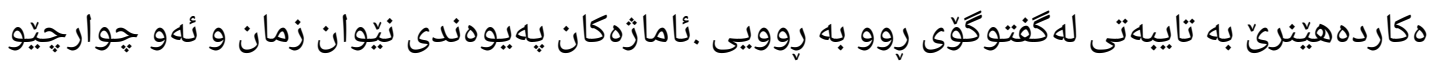

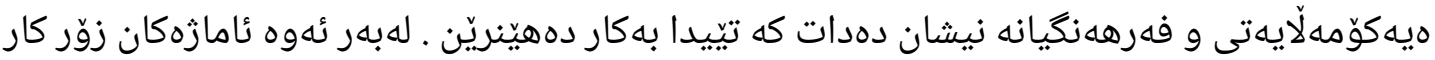
يكهرنله گفتوكوّ كردنى ههستهكان ماناى زياتر دهبه خشن بهو ووشانهى كه خهلّك به زارهكى دهيلّيّن . له كهلّئهوهشدا دهربرين و نيشاندانى ههست به ئامازمكان يشت به ريّسا كوّمهلَايهتيهكان دهبهستيّت . ئهمتويّزينهوهيه بهسهر سى بهشدا دابهش كراوه : بهشى يهكهم يرسيارهكانى تويّزينهوه و ئامانجيتو يّزينهوهكه رِوون دهكاتهوه . بهشى دووهم جهخت لهسهر باككراوندى تيوّريى تويّزينهوهكه دهكاتهوه

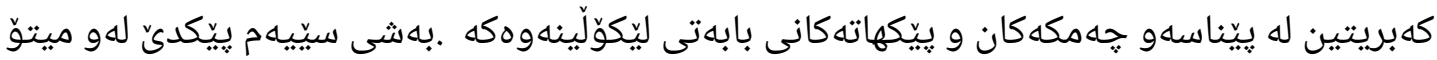

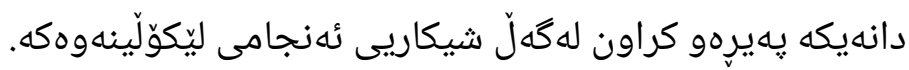

\section{فعالية وسائل التواصل الإيمائي لعرض المشاعر بالإشارة إلى الكردية والإنجليزية}

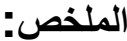

تهدف هذه الدراسة إلى التحقيق في فعالية وسائل التواصل التشجيجي في إظهار العواطف، التو اصل فئ غير اللفظي

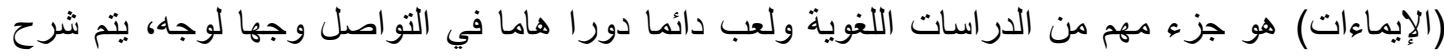

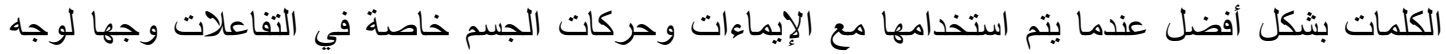

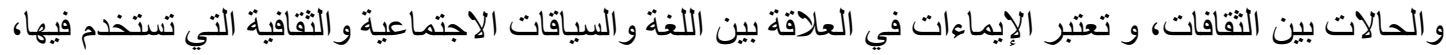

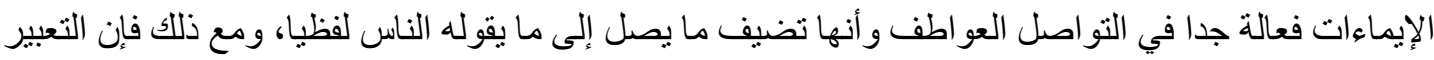

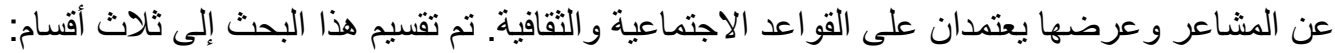

